\title{
Susceptibility of Clostridium difficile Toward Antimicrobial Agents Used as Feed Additives for Food Animals
}

\section{Aarestrup, Frank Møller; Tvede, Michael}

\section{Published in:}

Microbial Drug Resistance

Link to article, DOI:

10.1089/mdr.2010.0068

Publication date:

2011

Document Version

Publisher's PDF, also known as Version of record

Link back to DTU Orbit

Citation $(A P A)$ :

Aarestrup, F. M., \& Tvede, M. (2011). Susceptibility of Clostridium difficile Toward Antimicrobial Agents Used as Feed Additives for Food Animals. Microbial Drug Resistance, 17(1), 125-127.

https://doi.org/10.1089/mdr.2010.0068

\section{General rights}

Copyright and moral rights for the publications made accessible in the public portal are retained by the authors and/or other copyright owners and it is a condition of accessing publications that users recognise and abide by the legal requirements associated with these rights.

- Users may download and print one copy of any publication from the public portal for the purpose of private study or research.

- You may not further distribute the material or use it for any profit-making activity or commercial gain

- You may freely distribute the URL identifying the publication in the public portal 


\title{
Susceptibility of Clostridium difficile Toward Antimicrobial Agents Used as Feed Additives for Food Animals
}

\author{
Frank M. Aarestrup ${ }^{1}$ and Michael Tvede ${ }^{2}$
}

A total of 65 toxigenic Clostridium difficile strains isolated from patients with antibiotic-associated diarrhea were tested for susceptibility to avilamycin, flavomycin, monensin, and salinomycin. Except for flavomycin the substances showed in vitro efficacy comparable to reports of the currently most commonly used drugs for treatment of $C$. difficile. This indicates that these old compounds may be useful for the treatment of $C$. difficile infections in man and perhaps for other bacterial causes of diarrhea.

\section{Introduction}

$C^{\prime+a n d}$ LOSTRIDIUM DIFFICILE IS AN ANAEROBIC spore-forming and often toxin-producing Gram-positive bacterium and is a major cause of pseudomembraneous colitis and antibiotic-associated diarrhea mainly in patients previously administrated antimicrobials, as first described by Larson et al. ${ }^{15}$ and Bartlett et al. ${ }^{6}$

C. difficile infections have recently increased in incidence and severity in many regions of North America and many countries in Europe. ${ }^{13,20} \mathrm{C}$. difficile is intrinsically resistant to many antimicrobial agents, and acquired resistance to the few therapeutically efficient drugs has been rapidly increasing. ${ }^{18}$ The current treatment regime is associated with treatment failure in some cases and relapses occur in $\sim 20 \%$ $30 \%$ of all clinical cases. ${ }^{3}$ This has increased the interest in searching for novel and more efficient treatment options and the development of new antibiotics. ${ }^{5,13}$

A number of antimicrobial agents, never approved for human therapy, have for several decades been used for nontherapeutic purposes or to control coccidia infections in food animals. ${ }^{1,2}$ Some of these compounds have shown good in vitro activity against Clostridium perfringens 9,22 and have been also able to control infections with this bacterium in poultry ${ }^{19,21}$ and swine. ${ }^{14}$ These antimicrobials are included in the feed and are poorly absorbed in the gut. Thus, we speculated whether these compounds might have activity against $C$. difficile-caused gastrointestinal infections in humans.

This study was conducted to evaluate the in vitro susceptibility to avilamycin, flavomycin, monensin, and salinomycin against $C$. difficile isolated from infections in humans as a first step to determine their potential value as human therapeutic drugs.

\section{Materials and Methods \\ Bacterial isolates}

A total of 65 clinical isolates of $C$. difficile were selected from cases of antibiotic-associated diarrhea at Rigshospitalet in Denmark. The isolates were cultured from feces on cycloserine-cefoxitin-fructose egg yolk agar (Statens Serum Institute) and identified as $C$. difficile by usual routine fermentation tests and demonstration of volatile fatty acids by gas-liquid chromatography according to the manual of the Virginia Polytechnic Institute. ${ }^{11}$ Cytotoxin was demonstrated in a McCoy cell assay established in the laboratory at Rigshospitalet. $^{12}$

\section{Antimicrobial susceptibility testing}

All isolates were examined for their minimum inhibitory concentrations (MICs) using twofold dilutions on Brucella agar supplemented with 5\% laked sheep blood (Statens Serum Institute), $5 \mathrm{mg} / \mathrm{L}$ hemin (Sigma-Aldrich), and $1 \mathrm{mg} / \mathrm{L}$ vitamin K (Sigma-Aldrich) according to CLSI standards. ${ }^{8}$ Isolates were tested to the following concentrations of avilamycin (Elanco Animal Health), flavomycin (Hoechst $\mathrm{GmbH})$, monensin (Elanco Animal Health), and salinomycin (Huvepharma): 0.03, 0.06, 0.125, 0.25, 0.5, 1, 2, 4, 8, and $16 \mathrm{mg} / \mathrm{L}$. Avilamycin and monensin were dissolved in acetone, salinomycin in $99 \%$ ethanol, and flavomycin directly in water before being added to the agar. As quality control strain, C. difficile ATTC 17857 was included on all agar plates.

\footnotetext{
${ }^{1}$ EU Reference Laboratory for Antimicrobial Resistance, WHO Collaborating Centre for Antimicrobial Resistance in Foodborne Pathogens, National Food Institute, Technical University of Denmark, Lyngby, Denmark.

${ }^{2}$ Department of Clinical Microbiology, Rigshospitalet, University of Copenhagen, Copenhagen, Denmark.
} 
Table 1. Susceptibility of 65 Clinical Isolates of Clostridum difficile Toward Four Antimicrobial Agents Used as Feed Additives or as Coccidiostatica in Food Animals

\begin{tabular}{lcccccccc}
\hline & \multicolumn{7}{c}{ Number of isolates } \\
\cline { 2 - 9 } Antimicrobial agent & $0.03^{\mathrm{a}}$ & 0.06 & 0.13 & 0.25 & 0.5 & 1 & 2 & 4 \\
\hline Flavomycin & 1 & & & 2 & 2 & 3 & 17 & $32^{\mathrm{b}}$ \\
Monensin & 2 & 7 & 4 & 7 & 29 & $16^{\mathrm{b}}$ & & \\
Salinomycin & 8 & 4 & 15 & 20 & $18^{\mathrm{b}}$ & & 2 \\
Avilamycin & 1 & 9 & $23^{\mathrm{b}}$ & 30 & & &
\end{tabular}

${ }^{a}$ Values in this row indicate MICs $(\mathrm{mg} / \mathrm{L})$

${ }^{\mathrm{b}} \mathrm{MIC}$ of Clostridium difficile ATCC 17857.

MIC, minimum inhibitory concentration.

The agar plates were incubated under anaerobic conditions at $36^{\circ} \mathrm{C}$ for $42-48$ hours.

\section{Results}

The MICs are shown in Table 1 . MIC values for avilamycin ranged from $\leq 0.03$ to $0.25 \mathrm{mg} / \mathrm{L}$; two isolates, however, had MIC values of $2 \mathrm{mg} / \mathrm{L}$. MIC values for flavomycin ranged from 0.25 to $8 \mathrm{mg} / \mathrm{L}$, for monensin from $\leq 0.03$ to $1 \mathrm{mg} / \mathrm{L}$, and for salinomycin from $\leq 0.03$ to $0.5 \mathrm{mg} / \mathrm{L}$.

\section{Discussion}

Infections caused by $C$. difficile are increasing in prevalence and severity. Treatment of these infections is increasingly difficult because of the development of resistance toward fluoroquinolones and rifampicin and reduced clinical response to metronidazole and vancomycin. The use of vancomycin is further problematic because of the risk of selection for vancomycin-resistant enterococci and staphylococci.

We tested the in vitro susceptibility of $65 \mathrm{C}$. difficile isolates toward avilamycin, flavomycin, monensin, and salinomycin. All four compounds have been extensively used for decades in food animals and no toxicological reactions, to our knowledge, have been ever recorded. Avilamycin, an oligosaccharide, and another closely related antimicrobial agent, everninomicin, were previously under development for therapeutic use in humans. Avilamycin has been originally shown to bind to the $30 \mathrm{~S}$ subunit of ribosome and thereby interfere with the protein synthesis function. ${ }^{23}$ Everninomycin has, however, been shown to bind exclusively to the $50 \mathrm{~S}$ subunit. ${ }^{17}$ In enterococci, resistance to both compounds is mediated by either point mutations in the L16 50S subunit ribosomal protein ${ }^{4}$ or a methyltransferase acting on the $50 \mathrm{~S}$ subunit. ${ }^{16}$ Flavomycin is a phosphoglycopeptide that inhibits peptidoglycan synthesis by inhibiting peptidoglycan polymerases. ${ }^{7}$ Several bacterial species exhibit natural resistance to flavomycin, but so far acquired resistance has not been confirmed. ${ }^{7}$ Monensin and salinomycin are both ionophores and interfere with the natural ion transport system of both prokaryotic and eukaryotic cells. Staphylococcal and enterococcal isolates with reduced susceptibility has been reported, ${ }^{3}$ but the mechanism has never been elucidated. To our knowledge, no substances belonging to these classes have been ever developed for human usage.

All four substances tested had activity against $C$. difficile; however, flavomycin had relatively high MIC values, whereas avilamycin, monensin, and salinomycin had MIC values comparable to or slightly lower than those reported for metronidazole and vancomycin. ${ }^{10}$

These results indicate that some of these old compounds, which for decades have been used for other purposes, might find application in human medicine for the treatment of $C$. difficile diarrhea and perhaps other chronic diarrhea diseases. Further studies are, however, necessary to determine the therapeutic potential and also to explore whether some negative effects might be associated with a future use of one or more of these compounds in human medicine.

\section{Acknowledgments}

The authors are grateful to Jacob Dyring Jensen and Anette Gregersen for technical assistance. This study was funded by a grant (274-05-0117) from the Danish Research Agency.

\section{Disclosure Statement}

No competing financial interests exist.

\section{References}

1. Aarestrup, F.M. 2000. Occurrence, selection and spread of resistance to antimicrobial agents used for growth promotion for food animals in Denmark. APMIS 101 Suppl:1-48.

2. Aarestrup, F.M. 2005. Veterinary drug usage and antimicrobial resistance in bacteria of animal origin. Basic Clin. Pharmacol. Toxicol. 96:271-281.

3. Aarestrup, F.M., F. Bager, N.E. Jensen, M. Madsen, A. Meyling, and H.C. Wegener. 1998. Surveillance of antimicrobial resistance in bacteria isolated from food animals to antimicrobial growth promoters and related therapeutic agents in Denmark. APMIS 106:606-622.

4. Aarestrup, F.M., and L.B. Jensen. 2000. Presence of variations in ribosomal protein L16 corresponding to susceptibility of enterococci to oligosaccharides (Avilamycin and evernimicin). Antimicrob. Agents Chemother. 44:34253427.

5. Bartlett, J.G. 2009. New antimicrobial agents for patients with Clostridium difficile infections. Curr. Infect. Dis. Rep. 11:21-28.

6. Bartlett, J.G., T.W. Chang, M. Gurwith, S.L. Gorbach, and A.B. Onderdonk. 1978. Antibiotic-associated pseudomembraneous colitis due to toxin-producing clostridia. N. Engl. J. Med. 298:531-534. 
7. Butaye, P., L.A. Devriese, and F. Haesebrouck. 2003. Antimicrobial growth promoters used in animal feed: effects of less well known antibiotics on gram-positive bacteria. Clin. Microbiol. Rev. 16:175-188.

8. [CLSI] Clinical and Laboratory Standards Institute. 2007. Methods for antimicrobial susceptibility testing of anaerobic bacteria. Approved standard, $7^{\text {th }}$ edition. CLSI, Wayne, PA.

9. Devriese, L.A., G. Daube, J. Hommez, and F. Haesebrouck. 1993. In vitro susceptibility of Clostridium perfringens isolated from farm animals to growth-enhancing antibiotics. J. Appl. Bacteriol. 75:55-57.

10. Hecht, D.W., M.A. Galang, S.P. Sambol, J.R. Osmolski, S. Johnson, and D.N. Gerding. 2007. In vitro activities of 15 antimicrobial agents against 110 toxigenic Clostridium difficile clinical isolates collected from 1983 to 2004. Antimicrob. Agents Chemother. 51:2716-2719.

11. Holdeman, L.V., E.P. Cato, and W.E.C. Moore. 1977. Anaerobe Laboratory Manual, $4^{\text {th }}$ ed. Blacksburg, Virginia, Virginia Polytechnic Institute and State University.

12. Knudsen, J.D., and M. Tvede. 1993. Demonstration of toxin $\mathrm{A}$ and $\mathrm{B}$ by polymerase chain reaction and McCoy cell assay in clinical isolates of Clostridium difficile from Denmark. APMIS 101:18-22.

13. Kuijper, E.J., B. Coignard, and P. Tüll. 2006. Emergence of Clostridium difficile-associated disease in North America and Europe. Clin. Microbiol. Infect. 12 Suppl 6:2-18.

14. Kyriakis, S.C., K. Sarris, S.K. Kritas, A.C. Tsinas, and C. Giannakopoulos. 1996. Effect of salinomycin in the control of Clostridium perfringens type $\mathrm{C}$ infections in sucklings pigs. Vet. Rec. 138:281-283.

15. Larson, H.E., A.B. Price, P. Honour, and S.P. Boriello. 1978. Clostridium difficile and the aetiology of pseudomembranous colitis. Lancet 1:1063-1066.

16. Mann, P.A., L. Xiong, A.S. Mankin, A.S. Chau, C.A. Mendrick, D.J. Najarian, C.A. Cramer, D. Loebenberg, E. Coates, N.J. Murgolo, F.M. Aarestrup, R.V. Goering, T.A. Black, R.S. Hare, and P.M. McNicholas. 2001. EmtA, a rRNA methyltransferase conferring high-level evernimicin resistance. Mol. Microbiol. 41:1349-1356.
17. McNicholas, P.M., D.J. Najarian, P.A. Mann, D. Hesk, R.S. Hare, K.J. Shaw, and T.A. Black. 2000. Evernimicin binds exclusively to the $50 \mathrm{~S}$ ribosomal subunit and inhibits translation in cell-free systems derived from both gram-positive and gram-negative bacteria. Antimicrob. Agents Chemother. 44:1121-1126.

18. Rupnik, M., M.H. Wilcox, and D.N. Gerding. 2009. Clostridium difficile infection: new developments in epidemiology and pathogenesis. Nat. Rev. Microbiol. 7:526-536.

19. Stutz, M.W., and G.C. Lawton. 1984. Effects of diet and antimicrobials on growth, feed efficiency, intestinal Clostridium perfringens, and ileal weight of broiler chicks. Poult. Sci. 63:2036-2042.

20. Taubes, G. 2008. Collateral damage. The rise of resistant $C$. difficile. Science 321:360.

21. Vissiennon, T., H. Kröger, T. Köhler, and R. Kliche. 2000. Effect of avilamycin, tylosin and ionophore anticoccidials on Clostridium perfringens enterotoxaemia in chickens. Berl. Munch. Tierarztl. Wochenschr. 113:9-13.

22. Watkins, K.L., T.R. Shryock, R.N. Dearth, and Y.M. Saif. 1997. In-vitro antimicrobial susceptibility of Clostridium perfringens from commercial turkey and broiler chicken origin. Vet. Microbiol. 54:195-200.

23. Wolf, H. 1973. Avilamycin, an inhibitor of the $30 \mathrm{~S}$ ribosomal subunits function. FEBS Lett. 36:181-186.

Address correspondence to: Frank M. Aarestrup, D.V.M., Ph.D. EU Reference Laboratory for Antimicrobial Resistance WHO Collaborating Centre for Antimicrobial Resistance in Foodborne Pathogens National Food Institute Technical University of Denmark Kemitorvet, Building 204 DK-2800 Lyngby Denmark

E-mail: fmaa@food.dtu.dk 
